Ya. O. BABIYCHUK, D. S. NAZARENKO, I. V. SIEDYKH

\title{
CALCULATION AND EXPERIMENT METHOD TO STUDY PROPELLANT SETTLEMENT IN A TANK BEFORE SUSTAINER ENGINE RESTARTS
}

\author{
Yuzhnoye State Design Office \\ 3 Krivorozhskaya St., Dnipro 49008, Ukraine; e-mail: info@yuzhnoye.com
}

An orbital flight with long pauses between sustainer engine starts calls for engine starts in space, for which purpose the presence of the propellant at the feed line inlet must be assured. Since with the sustainer engine switched off the propellant is in nearly zero gravity and can move freely throughout the tank occupying almost any spatial position, the propellant must be moved to its pre-start position to assure a guaranteed restart of the sustainer engine. The propellant is moved to the feed lines by setting up a longitudinal acceleration using thrusters. The time it takes for the whole of the propellant to be moved from one position to the other is the most important parameter that affects the propellant amount and thus the stage energy characteristics.

This paper considers fuel settlement in the fuel tank of a launch vehicle's third stage with the use of two thrusters before a sustainer engine restart in the worst case where the whole of the remaining fuel is concentrated near the upper pole of the tank, which corresponds to the maximum distance to be traveled by the fuel and thus to the maximum settlement time.

The paper presents the authors' calculation and experiment method for determining the propellant settlement time, which combines an experimental study and a numerical simulation of propellant settlement, thus allowing one to conduct the necessary studies with a desired accuracy and significantly reduce the extent of testing and the need for material facilities.

The proposed method will make it possible to optimize the traditional procedure of settlement time calculation by assuring a more accurate determination of the settlement time as early as at the initial stage of development, thus reducing the volume of the propellant components required for the thruster operation with a corresponding increase in the payload mass.

Keywords propellant settlement, zero gravity research facility, hydrodynamic similarity, numerical simulation, propellant damping and separation.

1. Masica W.J., Petrash D.A. Motion of liquid-vapor interface in response to imposed acceleration. Lewis Research Center. NASA TND-3005, 1965. $24 \mathrm{pp}$.

2. Masica W.J., Petrash D.A., Otto E.W. Hydrostatic stability of liquid-vapor interface in a gravitational field. Lewis Research Center. NASA TND-2267, 1964. $18 \mathrm{pp}$

3. Burge G. W., Blackmon J. B. et al. Analytical approach to the design of orbital refueling systems.(in Russian). Collected translations, GONTI-4. 1970. Pp.. 56-111.

4. Gluck D. F., Gill D. P. Hydromechanics of propellant feed to the spacecraft propulsion system in zero gravity (in Russian). Konstruirovaniye i Tekhnologiya Mashinostroyeniya. 1965. V.87.Pp. 1-10.

5. Voss J. E. Hattis P. D. Problem of outflow control in the process of filling of the Space Shuttle tanks with liquid components in a near-Earth orbit (in Russian). Astronavtika I Raketodinamika. 1986. No. 7. Pp. 8-19.

6. Ring E. Liquid-Propellant Rocket Propulsion Systems (in Russian). Moscow: Mir, $1966.400 \mathrm{pp}$

7. Siedykh I. V., Smolensky D. E. Experimental verification of the capillary intake device operability in spacecraft separation (in Russian). Mechanics of Gyroscopic Systems. 2017. No. 33. Pp. 105-114. doi: 10.20535/02033771332017119618

8. Siedykh I. V., Smolensky D. E., Nazarenko D. S. Experimental verification of the capillary intake device (mesh separator) operability in a program slew maneuver (in Russian). Visnyk Dniprovskoho Universytetu. Seria Raketno-Kosmichna Tekhnika. 2018. V. 26. Iss. 21.Pp.112-119.

9. Bruyaka V. A., Fokin V. G. Soldusova E. A., Glazunova N. A., Adeyanov I. E. Engineering Analysis in ANSYS Workbench (in Russian). Samara: Samara State Technical University, 2010. 271 pp. 